\title{
Crystallographic control on lithium isotope fractionation in Archean to Cenozoic LCT pegmatites
} \author{
V. Ullmann ${ }^{4,5}$ \\ ${ }^{1}$ Universität Münster, Corrensstr. 24, D-48149 Münster, Germany \\ ${ }^{2}$ Czech Geological Survey, Klárov 3, CZ-118 21 Prague 1, Czech Republic \\ ${ }^{3}$ Masaryk University, Kotlářská 2, CZ-61137 Brno, Czech Republic \\ ${ }^{4}$ Freie Universität Berlin, Malteserstr. 74-100, D-12249 Berlin, Germany \\ 5University of Exeter, CSM \& ESI, Penryn Campus, TR10 9 FE Penryn, UK \\ *e-mail: tomas.magna@geology.cz; Telephone: +420-2-5108 5331
}

Tomáš Magna ${ }^{1,2, *}$, Milan Novák ${ }^{3}$, Jan Cempírek ${ }^{3}$, Vojtěch Janoušek², Uwe Wiechert ${ }^{4}$, and Clemens

\section{ABSTRACT}

The age distribution of lithium-cesium-tantalum (LCT) pegmatites largely overlaps with major phases of collisional orogenic events and assembly of super-continents. Some of the largest known LCT pegmatite deposits formed in very short intervals, 2.7-2.5 and 1.9-1.8 billion years ago (Ga), corresponding to two major pulses of continental crust growth. However, the exact process of generation and segregation of large volumes of $\mathrm{Li}$-bearing pegmatite liquids, perhaps involving disequilibrium fractional crystallization and leaving residual melts enriched in fluxing elements such as $\mathrm{B}, \mathrm{F}, \mathrm{H2O}$, Li, and $\mathrm{P}$, remains largely obscure. The new data on $\mathrm{Li}$ contents and isotope compositions in major mineral phases from temporally and geographically separated pegmatite bodies document extreme variations in $\delta^{7} \mathrm{Li}$ values among individual large LCT pegmatite bodies, in particular Archean occurrences. The observed $>\mathbf{1 0 \%}$ variations in $\delta^{7} \mathrm{Li}$ values for the same mineral phases from different localities (i.e., beryl, petalite, spodumene, lepidolite, amblygonite, muscovite) contrast with globally homogeneous Li isotope systematics of major mineral phases from unmodified mantle rocks. Consistent $\mathrm{Li}$ isotope offsets between coexisting mineral phases are best explained by $\mathrm{Li}$ isotope fractionation as a function of the bond length between $\mathrm{Li}$ and neighboring ions $(\mathrm{O}, \mathrm{OH}, \mathrm{F})$. We suggest that spatially distinct $\mathrm{Li}$ isotope patterns act as fingerprints for different pegmatites and can be explained by the pre-existing Li isotope differences of their crustal sources at the time of pegmatite formation owing to differences in crustal age and evolution. This would imply secular evolution of the continental crust over Earth history toward present-day globally broadly uniform crustal ${ }^{7} \mathrm{Li} /{ }^{6} \mathrm{Li}$ ratios $\left(\delta^{7} \mathrm{Li} \sim 0 \%\right)$. The differences among Archean occurrences could reflect possible Archean paleogeography and perhaps be linked with different thermal regimes of individual cratons as a consequence of variations in crustal thickness. One possible application of the new data set may be in source verification of gemquality stones by using $\mathrm{Li}$ isotopes.

\section{INTRODUCTION}

During the last several decades, lithium (Li) has become an important metal in many areas of human activity, such as in the nuclear, electronic, optical, ceramic, and glass industries (Kesler et al., 2012), demanding a variety of economic sources of Li, such as lithium-cesium-tantalum (LCT) pegmatites, commonly associated with S-type granitoid rocks (Černý et al., 2012). Contrary to large, slowly cooled granitic plutons, batches of pegmatite liquids intrude relatively cold country rocks and undergo rapid cooling. Due to the effects of their unusual bulk compositions, though, pegmatites develop a range of characteristic textures, including giant crystals and extreme mineralogical zonation. The same compositional anomalies - in particular the high contents of volatile species - serve to lower solidi (Bartels et al., 2015; Maneta et al., 2015), which may permit primary crystallization of LCT pegmatite cores at low temperatures and pressures, commonly $\sim 500-400{ }^{\circ} \mathrm{C}$ and $\sim 0.4-0.1 \mathrm{GPa}$ (London, 2008; Sirbescu and Nabelek, 2003). Nonetheless, accurate models for generation of Li-rich pegmatitic liquids are largely missing and the ultimate sources are unconstrained for many LCT pegmatite deposits (Supplementary information).

The response of $\mathrm{Li}$ isotopes to progressively evolving liquids in late evolutionary stages of felsic magmatic systems has been little studied so far although it may have important implications for unraveling the sources and histories of global economic deposits of Li and other rare metals, such as Ta, Sn, and Cs (Linnen et al., 2012). The high bulk Li contents of LCT pegmatites make them ideal to assess $\mathrm{Li}$ isotope fractionation during progressive crystallization at low to moderate temperatures and shallow depths (Wunder et al., 2006), well below the wet granite solidus (London and Morgan, 2012). Considering that evolved LCT pegmatites may crystallize Li-bearing phases whose Li coordination varies, these rocks are a natural target to study the impact of such changes on $\mathrm{Li}$ isotope fractionation. The large variations in $\delta^{7} \mathrm{Li}$ (per mil difference to L-SVEC reference material; see Methods and results) of pegmatites have variously been ascribed to: (i) extensive crystal-melt (magmatic) fractionation (Barnes et al., 2012; Teng et al., 2006), (ii) fractionation between the melt and exsolving fluid (Maloney et al., 2008), (iii) differences in crustal sources (Deveaud et al., 2015), or (iv) the ${ }^{7} \mathrm{Li}$ affinity to occupy stronger (i.e., shorter) Li-O bonds (Wunder et al., 2011). Because the coordination of $\mathrm{Li}$ in the crystal structures of pegmatite minerals varies and $\mathrm{Li}-\varphi$ bond distances $(\varphi=\mathrm{O}, \mathrm{OH}, \mathrm{F})-$ expressed as weighted mean distance (parameters developed for quantitative characterization of deformed polyhedra by Nespolo et al., 2001; see Supplementary information for further details) - may differ by $>0.5 \AA\left(\AA=10^{-10} \mathrm{~m}\right)$, pegmatites are an ideal target to explore the last hypothesis.

It is interesting to note that the preponderance of the world's most significant LCT pegmatite fields, such as Tanco (Canada), Bikita (Zimbabwe), Greenbushes, Londonderry, and Wodgina (Australia), were all generated at a similar time in the Archean (McCauley and Bradley, 2014; see Supplementary information), implying that formation of large volumes of pegmatite liquids must have operated uniformly in widely separated cratonic regions (Pesonen et al., 2012). In this study, we have 
measured $\mathrm{Li}$ abundance and isotope compositions in a variety of mineral phases common in granitic pegmatites (muscovite, beryl, spodumene, lepidolite, amblygonite, petalite, elbaite, schorl) from seven pegmatite bodies of contrasting magmatic ages spanning from the Archean $(\sim 2.65-2.53$ billion years ago (Ga): Tanco, Canada; Bikita, Zimbabwe; Greenbushes and Londonderry, both Australia) through Paleoproterozoic $(\sim 1.71 \mathrm{Ga}$; Black Hills, USA), Paleozoic ( 325 Ma; Nová Ves, Czech Republic), to the Cenozoic ( $\sim 7$ million years ago (Ma); Elba, Italy). In addition, less common Li-bearing phases (lithiophilite, lithiophosphate, holmquistite, eucryptite, cookeite) were also analyzed from Tanco. Further details on geology are given in Supplementary information.

\section{METHODS AND RESULTS}

The analytical methods for $\mathrm{Li}$ isolation, purification, and isotope measurements are detailed in Magna et al. (2004). Lithium concentrations and isotope compositions in a subset of samples were measured using an Element XR sector-field high-resolution inductively-coupled-plasma mass spectrometer (SF-HR-ICPMS; Thermo Scientific, Bremen, Germany) housed at the Freie Universität Berlin. Lithium abundances and isotope compositions in a second subset of samples were determined using a Neptune multiple-collector ICPMS (Thermo Scientific, Bremen, Germany), housed at the Czech Geological Survey. The results are reported in the $\delta$-notation relative to the L-SVEC reference solution (Flesch et al., 1973) and calculated as $\delta^{7} \mathrm{Li}(\%$ ) $=\left[\left({ }^{7} \mathrm{Li} /{ }^{6} \mathrm{Li}\right)_{\text {sample }} /\left({ }^{7} \mathrm{Li} /{ }^{6} \mathrm{Li}\right)_{\text {L-SVEC-1 }}\right] \times 1000$. The reproducibility of $\mathrm{Li}$ isotope measurements was assessed by replicate measurements of reference granite JG-2, rhyolite JR-2 and granodiorite JG-3 (Geol. Surv. Japan), prepared together with the unknown samples (see Supplementary Table DR2). The reproducibility was generally better than $\pm 1.0 \%$ o $(2$ s.d.; calculated from two to four individual measurements; cf. Košler et al., 2001; Misra and Froehlich, 2009) for SF-HR-ICPMS instrument while it was generally better than $\pm 0.4 \%$ o ( 2 s.d.) for the MC-ICPMS instrument.

Lithium concentrations in the studied minerals vary between 590 and $\sim 59,100 \mu \mathrm{g} / \mathrm{g}$ with $\sim 154,600 \mu \mathrm{g} / \mathrm{g}$ in a single analyzed specimen of lithiophosphate. The $\delta^{7} \mathrm{Li}$ values range from -2.0 to $+33.6 \%$ (see Supplementary Table DR3 for results), spanning the majority of the $\delta^{7} \mathrm{Li}$ range observed for bulk continental and mantle-derived rocks, as well as Earthsurface materials, including marine sediments, seawater, brines and river waters (Tomascak et al., 2016). Petalite, lepidolite and, in particular, spodumene and amblygonite are the major Li hosts, with muscovite, schorl and beryl containing a lesser share. Muscovite and lepidolite carry a lighter Li isotope signature compared to coexisting beryl with distinctly high $\delta^{7} \mathrm{Li}$; the other phases show intermediate $\delta^{7} \mathrm{Li}$ values. No clear relationship between $\mathrm{Li}$ contents and $\delta^{7} \mathrm{Li}$ values is observed either for individual mineral phases or individual localities. On the other hand, clear co-variations between Li isotope compositions and crystallographic parameters, in particular effective coordination number (ECoN) and weighted mean distance (WtMD; see Supplementary information for further details), are apparent.

\section{CRYSTALLOGRAPHIC CONTROL ON INTER-MIN- ERAL LI ISOTOPE VARIATIONS IN PEGMATITES}

The spread in $\delta^{7} \mathrm{Li}$ values for a single mineral phase from various localities is substantial: $>20 \%$ in case of beryl and
$>10 \%$ for each of the other major Li-bearing phases analyzed in this study (Figure 1). This variation goes far beyond the analytical uncertainty and is thus inherent to the samples. Lithium occupies specific sites with distinct coordination (generally 4, 5, or 6-fold; see Supplementary Table DR3 and Figure 1) in the crystal structures of these mineral phases (Wenger and Armbruster, 1991) and this occupancy is highly unlikely to differ between individual localities. This is clearly valid for mineral phases with simple crystal structures, such as spodumene (spd) and petalite (ptl), where $\mathrm{Li}$ is the major element and not merely a substituent. These mineral pairs show similar apparent fractionation factors $\delta^{7} \mathrm{Li}_{\text {ptl-spd }}\left(\delta^{7} \mathrm{Li}_{\mathrm{A}-\mathrm{B}}=\delta^{7} \mathrm{Li}_{\mathrm{A}}-\delta^{7} \mathrm{Li}_{\mathrm{B}}\right)$ where they have been measured (e.g., 8.1 and 9.9\% for Tanco and Bikita, respectively), despite distinctively different absolute $\delta^{7} \mathrm{Li}$ values in the minerals themselves. This relatively uniform intermineral fractionation also applies (with some variation) to other phases where $\mathrm{Li}$ is more susceptible to occupying multiple positions in the crystal structure (e.g., lepidolite (lpd); $\delta^{7} \mathrm{Lil}_{\mathrm{pd}-\mathrm{ptl}}=$ 7.0-9.2\%o). These considerable offsets are in stark contrast to $\delta^{7} \mathrm{Li}$ variation in major mantle mineral phases, such as olivine and pyroxene, which is limited to a few per mil when unmetasomatized samples are considered (Tomascak et al., 2016), although the possible effects of varying major-element systematics on Li distribution (e.g., albite-anorthite in plagioclase; Coogan, 2011) clearly demand further experimental work.

It is broadly accepted that $\mathrm{Li}$ isotope fractionation during crystallization varies as a function of $\mathrm{Li}$ coordination in the crystal structure (Teng et al., 2006). This process thus plays the determining role in the fractionation of $\mathrm{Li}$ isotopes among individual co-genetic mineral phases. Indeed, a broadly negative correlation between $\mathrm{Li}$ isotope compositions and effective coordination number (Figure 1) suggests that the latter provides, to some extent, the first-order approximation for the sorting of $\delta^{7} \mathrm{Li}$ of mineral phases. Qualitative predictions of $\mathrm{Li}$ isotope

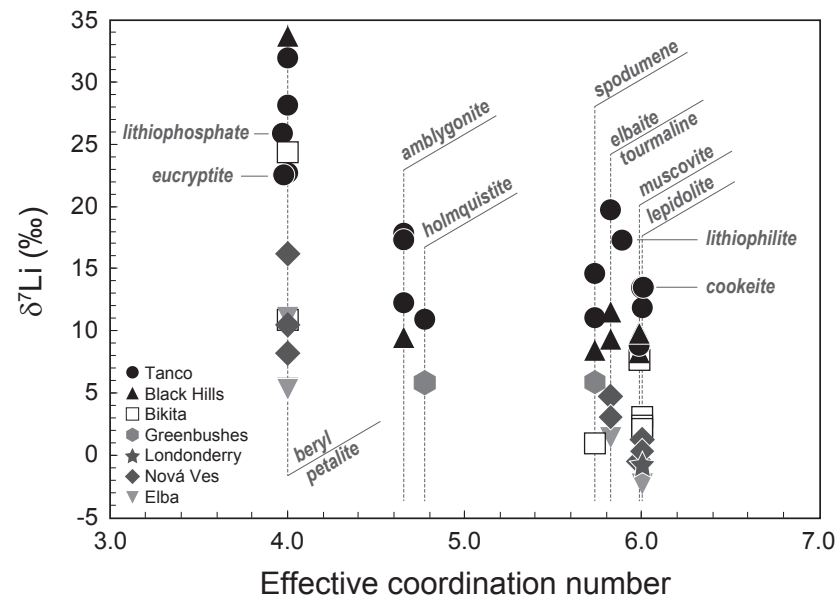

Figure 1. Lithium isotope composition versus effective coordination number (ECON) for mineral phases of LCT pegmatites. The first-order sorting of mineral phases is apparent with isotopically heavy phases (e.g., beryl, petalite) having low ECoN $\sim 4$ and isotopically light phases (e.g., muscovite, lepidolite, spodumene, tourmaline) having high ECoN $~ 6$. Large variations in $\mathrm{Li}$ isotope composition of individual mineral phases from different LCT pegmatite bodies are also evident. See Supplementary information for further details on ECoN.

fractionation based on the simple coordination rule, however, appear to describe the experimental data incompletely. There is some pressure control on $\mathrm{Li}$ isotope fractionation up to 8 
GPa (Kowalski and Jahn, 2011; Wunder et al., 2011), and theoretical (Kowalski and Jahn, 2011) as well as experimental (Wunder et al., 2006) evidence supports temperature-dependent fractionation of ${ }^{7} \mathrm{Li}$ into the fluid phase, effects of which diminish with increasing temperature. Whether the sense of $\mathrm{Li}$ isotope fractionation could be inverted in response to increasing coordination of $\mathrm{Li}$ in the supercritical fluid phase remains unclear at present (Kowalski and Jahn, 2011).

A more sophisticated expression of bonds in the mineral lattice is the bond valence model, which links the bond strength to the distance between the bonding partners (see Brown, 2002, for a review). This model has been successfully applied to predict $\mathrm{Li}$ isotope fractionation for a limited number of Li-bearing silicates (Wunder et al., 2011). The new data from Tanco, Bikita, Black Hills, Nová Ves and Elba support this interpretation, showing extremely well-correlated behavior of $\mathrm{Li}$ isotopes with the Li- $\varphi$ distance (Figure 2; a limited number of samples for Greenbushes and Londonderry precludes drawing more relevant conclusions). The parabolic shape of the best-fit curves appears

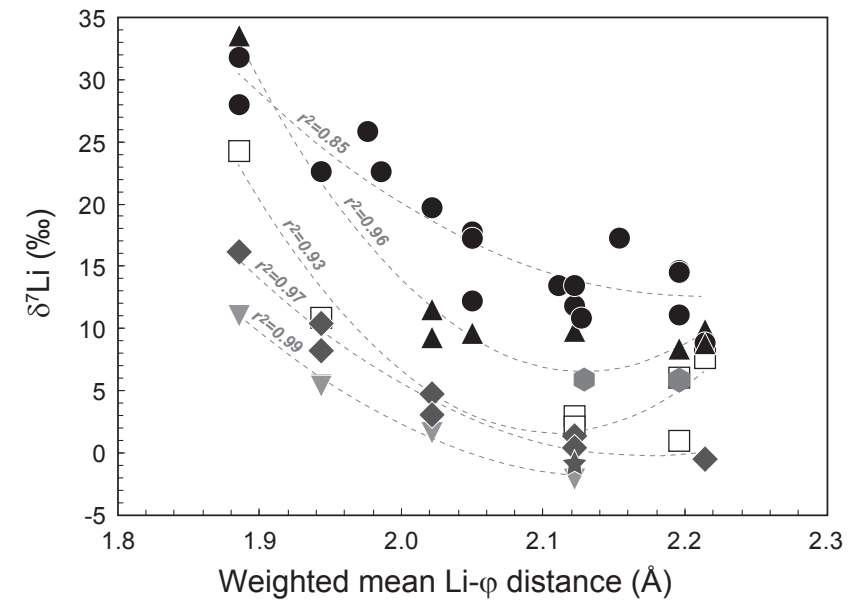

Figure 2. Lithium isotope composition versus weighted mean distance ( $\mathrm{Li}-\varphi ; \varphi=0, \mathrm{OH}, \mathrm{F}$ ) for mineral phases of LCT pegmatites. Near-parallel correlations are apparent for all investigated pegmatites, with $\mathbf{r}^{2}$ $>0.85$ in all cases, although for some localities the number of investigated samples was small. Symbols are as in Figure 1. See Supplementary information for further details on weighted mean distance.

to reflect the dependence of $\mathrm{Li}$ isotope fractionation on the bond valence of the $\mathrm{Li}$ site in the respective mineral structure more closely than a simple linear relationship because the function linking bond valence and bond length is curved (e.g., Brown, 2002). From near-identical shapes of the best-fit correlations in Figure 2 it follows that $\mathrm{Li}$ isotope fractionation factors for highly evolved magmatic liquids probably have global validity, i.e. are insensitive to tectonic setting, emplacement style, deposit age, and the activity of fluid-mobile elements such as B, F, or P. Moreover, they must also be insensitive to the degree of magmatic evolution of these residual liquids, as the data indicate no relative $\delta^{7} \mathrm{Li}$ distinction between mineral phases from chemically less evolved parts of pegmatite bodies (muscovite, schorl) versus those from highly evolved parts (petalite, spodumene, amblygonite, elbaite, lepidolite) versus sub-solidus breakdown products (cookeite, lithiophosphate).

The classical Rayleigh fractionation process would predict a uni-directional shift in $\delta^{7} \mathrm{Li}$ for a sequence of crystallizing phases from a hypothetical source with an originally uniform $\delta^{7} \mathrm{Li}$. None of the studied pegmatites shows this feature. Instead, Li isotope compositions converge from both low and high $\delta^{7} \mathrm{Li}$ values in contemporaneously crystallizing muscovite and beryl toward intermediate $\delta^{7} \mathrm{Li}$ values found in late solidus to early sub-solidus phases such as petalite, amblygonite and spodumene, and show high $\delta^{7} \mathrm{Li}$ variability in associated late hydrothermal phases (lithiophosphate, cookeite). This unequivocally demonstrates high mobility of $\mathrm{Li}$ in such $\mathrm{Li}-\mathrm{F}-\mathrm{B}-$ rich residues and in late-stage hydrothermal fluids (Maneta et al., 2015), particularly documented for large pegmatite bodies (e.g., Tanco; London, 2008). The development of systematic $\mathrm{Li}$ isotope heterogeneities/stratification during crystallization of pegmatite melts is thus largely impeded.

Possible contamination from the pegmatite host rock is negligible because alkalis ( $\mathrm{Li}, \mathrm{Cs}$, and $\mathrm{Rb}$ ) and other important rare metals may be enriched by a factor of up to 100,000 in pegmatites (Linnen et al., 2012). Such extreme enrichments coupled with rather low natural background of $\mathrm{Li}$ in normal silicate rocks (Tomascak et al., 2016) and the localized nature of pegmatites would require effective sequestering of $\mathrm{Li}$ from large volumes of country rock which is highly unlikely. For example, London (2008) calculated that $\sim 18,000 \mathrm{~km}^{3}$ of local country rock would be required to produce the Tanco pegmatite. Yet, Li is only moderately incompatible during melting (Brenan et al., 1998) and distribution coefficients higher than unity for mineral phases would necessitate significantly larger volumes of source country rocks than currently predicted. The observed Li enrichments must therefore be accounted for by other than local magmatic sources, perhaps by addition of formation waters and/or brines (Scholz et al., 2010) or employing specific processes, such as disequilibrium fractional crystallization combined with Li-supersaturation (Bartels et al., 2015; Deveaud et al., 2015; Maneta et al., 2015).

\section{REGIONAL LI ISOTOPE VARIATIONS IN PEGMA- TITES AND COROLLARY FOR LI IN THE CONTI- NENTAL CRUST}

A remarkable aspect of the new data set is the observation that Archean 2.6-2.5 Ga deposits (Tanco, Bikita, Greenbushes, Londonderry) display a mutual $\delta^{7} \mathrm{Li}$ offset extending $>10 \%$. This difference between pegmatites associated with predecessors (and parts of) of the Laurentian craton (Tanco, Black Hills) versus pegmatites from other cratonic settings (Bikita, Greenbushes, Londonderry) apparently precludes directly linking the Li isotope compositions of contemporaneous deposits with a single tectonic event or a uniform source (Deveaud et al., 2015). The observed variation in $\delta^{7} \mathrm{Li}$ values is also in stark contrast with a largely restricted $\delta^{7} \mathrm{Li}$ range in pristine mantle xenoliths (see recent summary in Tomascak et al., 2016). Available Li isotope data for bulk granites and associated rocks from terranes in Australia and North America are rather heterogeneous (Bottomley et al., 1999; Teng et al., 2004, 2006). Proterozoic gneisses and similar rocks from the Canadian shield tend towards higher $\delta^{7} \mathrm{Li}$ values, while Archean zircons from the Jack Hills (Australia) - thought to reflect Li isotope systematics of their protoliths - show predominantly low $\delta^{7} \mathrm{Li}$ values (Ushikubo et al., 2008). Whether or not this diversity in possible granitic parentage accounts for the overall $\delta^{7} \mathrm{Li}$ difference among worldwide Archean LCT pegmatites remains unclear. Contrary to mature continental crust of Australia, juvenile continental crust of Laurentia would be reflected in 'mantle' $\mathrm{Li}$ isotope systematics of high-silica rocks.

For Variscan to sub-recent European occurrences of pegmatites, mature continental crust might have been sourced that carried predominantly light Li isotope compositions (Magna et al., 2010; Romer et al., 2014), reflecting long-term rework- 
ing through multiple episodes of crustal re-melting and weathering. Indeed, the secular evolution of crustal Li was already sketched by Elliott et al. (2004); Sauzéat et al. (2015) provides the most recent estimate of $\delta^{7} \mathrm{Li}=0.6 \pm 0.6 \%(2 \sigma)$ for the upper continental crust which is different to the estimate of the pristine mantle $\delta^{7} \mathrm{Li}$ value $(3.5 \pm 1.0 \%$, $2 \sigma$; Jeffcoate et al., 2007; Magna et al., 2006; Pogge von Strandmann et al., 2011) and global mantle-derived melts $\left(\delta^{7} \mathrm{Li}=3.4 \pm 1.4 \%\right.$, $2 \sigma$; Tomascak et al., 2008).

Moreover, there is also notable tendency toward lower $\delta^{7} \mathrm{Li}$ values with decreasing magmatic age in the same cratonic region. In the present data set, this feature is illustrated by the $\delta^{7} \mathrm{Li}$ offset observed for Tanco versus Black Hills (and even lower $\delta^{7} \mathrm{Li}$ values found for the $\sim 90 \mathrm{Ma}$ Little Nahanni Pegmatite, paralleled by correspondingly low $\delta^{7} \mathrm{Li}$ in regional granites, Canada; Barnes et al., 2012) and Nová Ves versus Elba, respectively. In particular, the $\sim 325$ Ma Nová Ves pegmatite shows resolvedly higher $\delta^{7} \mathrm{Li}$ values in mineral phases compared with the $\sim 7$ Ma Elba pegmatite having the lowest $\delta^{7} \mathrm{Li}$ values of the whole suite. Because there is no significant $\mathrm{Li}$ isotope fractionation during crustal anatexis (Teng et al., 2004), both $\delta^{7} \mathrm{Li}$ offset and absolute $\delta^{7} \mathrm{Li}$ values appear to be unrelated to high-temperature magmatic fractionation of parental granitic plutons.

The $\mathrm{Li}$ isotope systematics of large LCT pegmatite fields, in particular contemporaneous Archean occurrences, may provide further support for the existence of independent super-cratons in the Archean (Bleeker, 2003) with individual magmatic and post-magmatic histories, perhaps reflected in distinctively different $\delta^{7} \mathrm{Li}$. The exact cause of these observations is yet unclear but it could be linked with different thermal regimes of individual cratons as a consequence of variations in crustal thickness (Coltice et al., 2009; Rey et al., 2003), which would impart different extent of melting of shallow mature/juvenile regions. However, the intriguing possibility of employing $\mathrm{Li}$ isotopes as a tracer of previous mantle/crust history remains to be explored further with targeted studies.

Regardless of the ultimate causes for the above discussed heterogeneities, it appears that Li isotopes also provide the firstorder constraints on the nature and provenance of gem-quality precious stones such as tourmaline or beryl (Ludwig et al., 2011). The unique $\delta^{7} \mathrm{Li}$ fingerprints of different pegmatites can thus be useful for the certification of tourmaline provenance or unraveling illegal, human-induced modifications to these precious stones (see also Marschall and Jiang, 2011). The high $\mathrm{Li}$ contents in pegmatite-forming minerals and increasing availability of cost-effective and precise analytical techniques may preclude adulteration of gem-quality stones, once a comprehensive global database for pegmatite $\delta^{7} \mathrm{Li}$ values is available.

\section{ACKNOWLEDGMENTS}

We thank Stanislav Houzar for some samples from Tanco, Nová Ves, Black Hills and Elba, William Birch, Friedrich Koller and Josef Klomínský for samples from Greenbushes, Bikita and Londonderry, Mona-Lisa Sirbescu for spodumene 40-5 and amblygonite 131-13, Ralf Dohmen and Bernd Wunder for information, and Paul Tomascak for comments. We acknowledge journal reviews by Laurence Coogan, Lee Groat and an anonymous, as well as editorial handling and patience by Brendan Murphy. This study was supported by the Czech Science Foundation grants to VJ (205/07/0992), MN and JC (P210/14/13347S), and TM (P210/12/1990). CVU acknowledges funding from the Leopoldina - German National Academy of Sciences (grant no LPDS 2014-08).

\section{REFERENCES CITED}

Barnes, E.M., Weis, D., and Groat, L.A., 2012, Significant Li isotope fractionation in geochemically evolved rare element-bearing pegmatites from the Little Nahanni Pegmatite Group, NWT, Canada: Lithos, v. 132-133, p. 21-36, doi:10.1016/j.lithos.2011.11.014

Bartels, A., Behrens, H., Holtz, F., and Schmidt, B.C., 2015, The effect of lithium on the viscosity of pegmatite forming liquids: Chemical Geology, v. 410, p. 1-11, doi:10.1016/j.chemgeo.2015.05.011.

Bleeker, W., 2003, The late Archean record: A puzzle in ca. 35 pieces: Lithos, v. 71, p. 99-134, doi:10.1016/j.lithos.2003.07.003.

Bottomley, D.J., Katz, A., Chan, L.H., Starinsky, A., Douglas, M., Clark, I.D., and Raven, K.G., 1999, The origin and evolution of Canadian Shield brines: Evaporation or freezing of seawater? New lithium isotope and geochemical evidence from the Slave craton: Chemical Geology, v. 155, p. 295-320, doi:10.1016/S0009-2541(98)00166-1.

Brenan, J.M., Neroda, E., Lundstrom, C.C., Shaw, H.F., Ryerson, F.J., and Phinney, D.L., 1998, Behaviour of boron, beryllium and lithium during melting and crystallization: Constraints from mineral-melt partitioning experiments: Geochimica et Cosmochimica Acta, v. 62, p. 2129-2141, doi:10.1016/S0016-7037(98)00131-8.

Brown, I.D., 2002, The chemical bond in inorganic chemistry: The bond valence model, IUCr Monographs on Crystallography 12: Oxford, UK, Oxford University Press, $278 \mathrm{p}$.

Černý, P., London, D., and Novák, M., 2012, Granitic pegmatites as reflections of their sources: Elements (Quebec), v. 8, p. 289-294, doi:10.2113/ gselements.8.4.289.

Coltice, N., Bertrand, H., Rey, P., Jourdan, F., Phillips, B.R., and Ricard, Y., 2009, Global warming of the mantle beneath continents back to the Archaean: Gondwana Research, v. 15, p. 254-266, doi:10.1016/j.gr.2008.10.001.

Coogan, L.A., 2011, Preliminary experimental determination of the partitioning of lithium between plagioclase crystals of different anorthite contents: Lithos, v. 125, p. 711-715, doi:10.1016/j.lithos.2011.03.016.

Deveaud, S., Millot, R., and Villaros, A., 2015, The genesis of LCT-type granitic pegmatites, as illustrated by lithium isotopes in micas: Chemical Geology, v. 411, p. 97-111, doi:10.1016/j.chemgeo.2015.06.029.

Elliott, T., Jeffcoate, A., and Bouman, C., 2004, The terrestrial Li isotope cycle: light-weight constraints on mantle convection: Earth and Planetary Science Letters, v. 220, p. 231-245, doi:10.1016/S0012-821X(04)00096-2.

Flesch, G.D., Anderson, A.R., and Svec, H.J., 1973, A secondary isotopic standard for $6 \mathrm{Li} / 7 \mathrm{Li}$ determinations: International Journal of Mass Spectrometry and Ion Physics, v. 12, p. 265-272, doi:10.1016/0020-7381(73)80043-9.

Jeffcoate, A.B., Elliott, T., Kasemann, S.A., Ionov, D., and Cooper, K.M., 2007, $\mathrm{Li}$ isotope fractionation in peridotites and mafic melts: Geochimica et Cosmochimica Acta, v. 71, p. 202-218, doi:10.1016/j.gca.2006.06.1611.

Kesler, S.E., Gruber, P.W., Medina, P.A., Keoleian, G.A., Everson, M.P., and Wallington, T.J., 2012, Global lithium resources: Relative importance of pegmatite, brine and other deposits: Ore Geology Reviews, v. 48, p. 55-69, doi:10.1016/j.oregeorev.2012.05.006.

Košler, J., Kučera, M., and Sylvester, P., 2001, Precise measurement of Li isotopes in planktonic foraminiferal tests by quadrupole ICPMS: Chemical Geology, v. 181, p. 169-179, doi:10.1016/S0009-2541(01)00280-7.

Kowalski, P.M., and Jahn, S., 2011, Prediction of equilibrium Li isotope fractionation between minerals and aqueous solutions at high $\mathrm{P}$ and $\mathrm{T}$ : An efficient ab initio approach: Geochimica et Cosmochimica Acta, v. 75, p. 6112-6123, doi:10.1016/j.gca.2011.07.039

Linnen, R.L., Van Lichterverde, M., and Černý, P., 2012, Granitic pegmatites as sources of strategic metals: Elements (Quebec), v. 8, p. 275-280, doi:10.2113/gselements.8.4.275.

London, D., 2008, Pegmatites: The Canadian Mineralogist Special Publication $10,347 \mathrm{p}$.

London, D., and Morgan, G.B., 2012, The pegmatite puzzle: Elements (Quebec), v. 8, p. 263-268, doi:10.2113/gselements.8.4.263.

Ludwig, T., Marschall, H.R., Pogge von Strandmann, P.A.E., Shabaga, B.M., Fayek, M., and Hawthorne, F.C., 2011, A secondary ion mass spectrometry (SIMS) re-evaluation of $\mathrm{B}$ and $\mathrm{Li}$ isotopic compositions of $\mathrm{Cu}$-bearing elbaite from three global localities: Mineralogical Magazine, v. 75, p. 2485-2494, doi:10.1180/minmag.2011.075.4.2485.

Magna, T., Wiechert, U.H., and Halliday, A.N., 2004, Low-blank separation and isotope ratio measurement of small samples of lithium using multiplecollector ICPMS: International Journal of Mass Spectrometry, v. 239, p. 67-76, doi:10.1016/j.ijms.2004.09.008.

Magna, T., Wiechert, U., and Halliday, A.N., 2006, New constraints on the lithium isotope compositions of the Moon and terrestrial planets: Earth and Planetary Science Letters, v. 243, p. 336-353, doi:10.1016/j. eps1.2006.01.005.

Magna, T., Janoušek, V., Kohút, M., Oberli, F., and Wiechert, U., 2010, Fingerprinting sources of orogenic plutonic rocks from Variscan belt with lithium isotopes and possible link to the subduction-related origin of some 
A-type granites: Chemical Geology, v. 274, p. 94-107, doi:10.1016/j. chemgeo.2010.03.020.

Maloney, J.S., Nabelek, P.I., Sirbescu, M.-L.C., and Halama, R., 2008, Lithium and its isotopes in tourmaline as indicators of the crystallization process in the San Diego County pegmatites, California, USA: European Journal of Mineralogy, v. 20, p. 905-916, doi:10.1127/0935-1221/2008/0020-1823.

Maneta, V., Baker, D.R., and Minarik, W., 2015, Evidence for lithium-aluminosilicate supersaturation of pegmatite-forming melts: Contributions to Mineralogy and Petrology, v. 170, doi:10.1007/s00410-015-1158-z.

Marschall, H.R., and Jiang, S.-Y., 2011, Tourmaline isotopes: No element left behind: Elements (Quebec), v. 7, p. 313-319, doi:10.2113/ gselements.7.5.313.

McCauley, A., and Bradley, D.C., 2014, The global age distribution of granitic pegmatites: The Canadian Mineralogist, v. 52, p. 183-190, doi:10.3749/ canmin.52.2.183.

Misra, S., and Froehlich, P.N., 2009, Measurement of lithium isotope ratios by quadrupole-ICP-MS: Application to seawater and natural carbonates: Journal of Analytical Atomic Spectrometry, v. 24, p. 1524-1533, doi:10.1039/b907122a.

Nespolo, M., Ferraris, G., Ivaldi, G., and Hoppe, R., 2001, Charge distribution as a tool to investigate structural details. II. Extension to hydrogen bonds, distorted and hetero-ligand polyhedra: Acta Crystallographica B, v. 57, p. 652-664, doi:10.1107/S0108768101009879.

Pesonen, L.J., Mertanen, S., and Veikkolainen, T., 2012, Paleo-Mesoproterozoic supercontinents - A paleomagnetic view: Geophysica, v. 48, p. 5-47.

Pogge von Strandmann, P.A.E., Elliott, T., Marschall, H.R., Coath, C., Lai, Y.-J., Jeffcoate, A.B., and Ionov, D.A., 2011, Variations of Li and Mg isotope ratios in bulk chondrites and mantle xenoliths: Geochimica et Cosmochimica Acta, v. 75, p. 5247-5268, doi:10.1016/j.gca.2011.06.026.

Rey, P.F., Philippot, P., and Thébaud, N., 2003, Contribution of mantle plumes, crustal thickening and greenstone blanketing to the $2.75-2.65$ Ga global crisis: Precambrian Research, v. 127, p. 43-60, doi:10.1016/S0301-9268(03)00179-7.

Romer, R.L., Meixner, A., and Förster, H.-J., 2014, Lithium and boron in lateorogenic granites - Isotopic fingerprints for the source of crustal melts? Geochimica et Cosmochimica Acta, v. 131, p. 98-114, doi:10.1016/j. gca.2014.01.018.
Sauzéat, L., Rudnick, R.L., Chauvel, C., Garçon, M., and Tang, M., 2015, New perspectives on the $\mathrm{Li}$ isotopic composition of the upper continental crust and its weathering signature: Earth and Planetary Science Letters, v. 428, p. 181-192, doi:10.1016/j.epsl.2015.07.032.

Scholz, F., Hensen, C., De Lange, G.J., Haeckel, M., Liebetrau, V., Meixner, A., Reitz, A., and Romer, R.L., 2010, Lithium isotope geochemistry of marine pore waters - Insights from cold seep fluids: Geochimica et Cosmochimica Acta, v. 74, p. 3459-3475, doi:10.1016/j.gca.2010.03.026.

Sirbescu, M.-L.C., and Nabelek, P.I., 2003, Crustal melts below $400^{\circ} \mathrm{C}$ : Geology, v. 31, p. 685-688, doi:10.1130/G19497.1.

Teng, F.-Z., McDonough, W.F., Rudnick, R.L., Dalpé, C., Tomascak, P.B., Chappell, B.W., and Gao, S., 2004, Lithium isotopic composition and concentration of the upper continental crust: Geochimica et Cosmochimica Acta, v. 68, p. 4167-4178, doi:10.1016/j.gca.2004.03.031.

Teng, F.-Z., McDonough, W.F., Rudnick, R.L., Walker, R.J., and Sirbescu, M.L.C., 2006, Lithium isotopic systematics of granites and pegmatites from the Black Hills, South Dakota: American Mineralogist, v. 91, p. 14881498, doi:10.2138/am.2006.2083.

Tomascak, P.B., Langmuir, C.H., le Roux, P.J., and Shirey, S.B., 2008, Lithium isotopes in global mid-ocean ridge basalts: Geochimica et Cosmochimica Acta, v. 72, p. 1626-1637, doi:10.1016/j.gca.2007.12.021.

Tomascak, P.B., Magna, T., and Dohmen, R., 2016, Advances in lithium isotope geochemistry: Cham, Switzerland, Springer International Publishing, 200 p, doi:10.1007/978-3-319-01430-2.

Ushikubo, T., Kita, N.T., Cavosie, A.J., Wilde, S.A., Rudnick, R.L., and Valley, J.W., 2008, Lithium in Jack Hills zircons: Evidence for extensive weathering of Earth's earliest crust: Chemical Geology, v. 272, p. 666-676.

Wenger, M., and Armbruster, T., 1991, Crystal chemistry of lithium: Oxygen coordination and bonding: European Journal of Mineralogy, v. 3, p. 387400, doi:10.1127/ejm/3/2/0387.

Wunder, B., Meixner, A., Romer, R.L., and Heinrich, W., 2006, Temperaturedependent isotopic fractionation of lithium between clinopyroxene and high-pressure hydrous fluids: Contributions to Mineralogy and Petrology, v. 151 , p. 112-120, doi:10.1007/s00410-005-0049-0.

Wunder, B., Meixner, A., Romer, R.L., and Jahn, S., 2011, Li-isotope fractionation between silicates and fluids: Pressure dependence and influence of the bonding environment: European Journal of Mineralogy, v. 23, p. 333-342, doi:10.1127/0935-1221/2011/0023-2095. 